\title{
Effect of Storage Temperature on African Catfish (Clarias Gariepinus Burchell 1822) Milt Quality
}

\author{
Idahor K. O. ${ }^{1}$, Okunsebor S. A. ${ }^{2}$, Sokunbi O. A. ${ }^{3}$, Osaiyuwu O. H. ${ }^{3}$, Osayande U. D. ${ }^{3}$, \\ Hamza J. ${ }^{1}$, Is ah N. ${ }^{2}$ \\ ${ }^{1}$ Department of Animal Science, Nasarawa State University, Keffi, Shabu-Lafia Campus, P.M.B. 135, Lafia, \\ 950101, Nigeria. \\ ${ }^{2}$ Department of Aquaculture and Fisheries Management, Nasarawa State University, Keffi, Shabu-Lafia \\ Campus, P.M.B. 135, Lafia, 950101, Nigeria . \\ ${ }^{3}$ Animal Science Department, Faculty of Agriculture and Forestry, University of Ibadan, Ibadan, Nigeria . \\ *Corresponding Author: Idahor K. O, Department of Animal Science, Nasarawa State University, Keffi, \\ Shabu-Lafia Campus, P.M.B. 135, Lafia, 950101, Nigeria.
}

\begin{abstract}
African catfish (C. gariepinus) does not reproduce in captive, hence the adoption of artificial breeding strategy. This study was targeted at the possibility of storing milt at different temperatures, to ensure all-year-round breeding operation. To accomplish this aim, milt was harvested from a total of twelve African catfish and stored at three different temperatures designated as treatments $T 1\left(26.3^{\circ} \mathrm{C}\right)$ : Bench temperature (control: without refrigeration), T2 $\left(7.42^{\circ} \mathrm{C}\right)$ : Fridge temperature and $\mathrm{T} 3\left(1.3^{\circ} \mathrm{C}\right)$ : Freeze temperature. Results indicated that the room and testes temperature values were constantly $36.4^{\circ} \mathrm{C}$ and $26.0^{\circ} \mathrm{C}$, standard body and total body length values ranged from 42 to $43 \mathrm{~cm}$ and 48 to $50 \mathrm{~cm}$ respectively. While the papilla length value varied from 1.5 to $1.8 \mathrm{~cm}$, the fin length value was between 8.5 and $13.3 \mathrm{~cm}$. The sperm cells concentration value was as high as $5.62-6.54 \times 10^{9}$ across the treatments and the alive sperm cells were up to $75-79 \%$ at 0 minute but deteriorated to as low as $1.5-4 \%$ at 15 minutes. Though some alive and motile sperm cells were observed at 1 hour, the percentage was as low as $0.25 \%$, suggesting that catfish milt stored without cryopreservation might not be viable in artificial breeding.
\end{abstract}

Keywor ds: African catfish, artificial breeding, milt storage, refrigeration,

\section{INTRODUCTION}

African catfish is believed to be native of Africa with a wide geographical distribution within the continent. It belongs to the family of Claridae consisting of about 14 genera, 5 subgenera and 32 species including Clarias, Clarioides, Anguillo, Platycephaloides and Brevicephaloides [1, 2, 3]. Clarias gariepinus is one of the most suitable species for aquaculture in Africa attaining about a $\mathrm{kg}$ body weight at about 6 months of age especially under intensive management conditions. It was reported that $C$. gariepinus was hardy and adapted to diverse environments even with poor water quality [4]. It is highly cherished by many Nigerians, hence it commands very high commercial value and it is the most popular cultured fish in the country though still at subsistence level.

Unfortunately, C. gariepinus does not breed in captive hence, some artificial breeding approaches [5, 6 and 7]. Meanwhile, C. gariepinus eggs, larvae, fry and fingerlings could be collected from natural environment for stocking but may not be available all-year-round [8,9, 10, and 11]. Thus, it was suggested [12] that systematic pond propagation method would ensure fish production all-year-round.

In this method, the female is injected with an appropriate hormone to facilitate oocyte development and egg maturation prior to spawning. Regrettably, the male must be killed to obtain the milt resulting in scarcity of male brood stock. In some cases, the milt is harvested from many males depending on the commercial status of the farm yet, either the harvested milt is not enough warranting killing of more males or is in excess of what is needed. This often led to colossal losses.

At the moment, there is little or no information on alternative means of reducing this colossal wastage except, the use of syringe attempted by [13], cryopreservation technique propounded by [14] and 
simulation of natural conditions with little or no considerable natural spawning tendency $[5,6,15$, 16]. Since all these procedures necessitated the use of suitable reagents and high technical-knowhow, it may not be practicable at the farmstead level in Nigeria.

Moreover, milt quality is measured with the potency or ability to successfully fuse with the stripped eggs. This may not be achievable if the harvested milt is kept longer than necessary outside the fish. Essentially, spermatozoa fertilizing ability depends on composition of seminal fluid, milt volume, spermatozoa density and motility $[17,18,19]$.

Most commercial hatcheries where African catfish seeds are propagated, inadequate quantity and quality of milt always result in breeding failure [20]. Consequently, this study was aimed at the possibility of storing C. gariepinus milt at different temperature for subsequent utilization in artificial insemination. This may possibly ensure all-year-round breeding plan in fish as obtainable in most livestock artificial insemination programs.

\section{Materials AND Methods}

\subsection{Experimental Design and Fish Welfare}

Twelve male C. gariepinus brood stock weighing between 0.61 and $0.66 \mathrm{~kg}$ were bought from a sales outlet in Bukan Sidi, Lafia and were transported in jerry can containing clean water to Animal Science Laboratory, Faculty of Agriculture, Nasarawa State University, Keffi, Shabu-Lafia Campus. The fish were assigned to three treatments in a completely randomised design based on live weight. The treatments were Bench temperature (T1) (control: without refrigeration), Fridge temperature (T2) and Freeze temperature (T3) and each treatment had four replicates. This experiment was carried out purely as an observational work so, ethical permission was not considered necessary.

\subsection{Data Collection and Analysis}

Immediately on arrival, the twelve fish were transferred into an open bowl containing clean water where each of them was picked and weighed using table scale (Five Goats $\left.{ }^{\circledR}\right)$ to obtain live weight. The standard body length was taken from the mouth to the caudal fin base, while the total body length was taken from the mouth to the end of the caudal fin using measuring tape (Butterfly®). Papilla length, left and right fin length were measured using measuring tape (Butterfly®).

Thereafter, all the fish were sacrificed by percussive stunning the head above the eyes to impact on the brain with a blunt object until the fish was unconscious. The abdomen was carefully cut open and thermometer was placed on the testes directly to obtain testes temperature. Another thermometer was hung on the wall to obtain room temperature and a separate one was used in monitoring the refrigerator temperature. The left and right testes were collected carefully and the length was taken using measuring tape (Butterfly $\left.{ }^{\circledR}\right)$. The testes were carefully incised using surgical blade and the milt was gently squeezed out into Eppendorf tube, to measure the volume and the milt $\mathrm{pH}$ was determined with a $\mathrm{pH}$ strip. The harvested milt from the four replicates in each treatment was pooled, stirred gently with a spatula and stored on the Bench, in the Fridge and Freezer temperature respectively.

The pooled milt was processed for quality evaluation according to the procedures of [21] and [22]. Aliquot of the processed milt was taken with a micropipette and a drop was collected with a microscope slide, covered with a slip and viewed in a microscope (Olympus Microscope ${ }^{\circledR}$ Tokyo, Japan) at 10x and 40x magnifications, to determine alive and dead spermatozoa cells, active and sluggish spermatozoa cells as well as spermatozoa cells concentration as reported [23]. The pooled milt was always returned to the appropriate position promptly and this procedure was repeated every 15 minutes until no more motile spermatozoon was observed. Meanwhile, values of the milt volume and sperm cells concentration were determined only at 0 minute.

All the sets of data collected were subjected to analysis of variance according to statistical procedure of [24] and where applicable, the mean values were separated based on Duncan Multiple Range Test of the same software package.

\section{RES ULTS}

Table 1 presents the temperature and body linear parameters of the experimental catfish. There were statistical differences $(\mathrm{P}<0.05)$ in all the parameters measured except in room and testes temperature values. The milt storage temperature value was coolest $\left(1.3^{\circ} \mathrm{C}\right)$ in $\mathrm{T}_{3}$ followed by $\mathrm{T}_{2}\left(7.42^{\circ} \mathrm{C}\right)$ and $\mathrm{T}_{1}$ $\left(26.3^{\circ} \mathrm{C}\right)$ in that arrangement. The live weight value ranged from 0.61 to $0.64 \mathrm{~kg}$, standard body length 
(42.4 to $43.1 \mathrm{~cm}$ ), total body length $\left(48.2\right.$ to $50.2 \mathrm{~cm}$ ) and the papilla length varied from $1.5 \mathrm{~cm}$ in $\mathrm{T}_{2}$ to $1.8 \mathrm{~cm}$ in $\mathrm{T}_{1}$. The left fin length was as short as $8.5 \mathrm{~cm}$ in $\mathrm{T}_{2}$ compared to $13.3 \mathrm{~cm}$ recorded in $\mathrm{T}_{3}$. Whereas, the right fin length was not significantly different $(P>0.05)$ in both $T_{1}$ and $T_{3}$ but the mean values were statistically different $(\mathrm{P}<0.05)$ from $13.3 \mathrm{~cm}$ recorded in $\mathrm{T}_{2}$. While the left testis length mean value ranged from $4.69 \mathrm{~cm}$ in $T_{1}$ to $5.5 \mathrm{~cm}$ in $T_{3}$, the right testis was as long as $6.1 \mathrm{~cm}$ in $T_{2}$.

Table1. Temperature parameters and body linear measurements of the experimental catfish

\begin{tabular}{|c|c|c|c|}
\hline \multirow[b]{2}{*}{ Parameters } & \multicolumn{3}{|c|}{ Treatments ( \pm STD) } \\
\hline & $\mathbf{T}_{1}$ & $\mathbf{T}_{2}$ & $\mathbf{T}_{\mathbf{3}}$ \\
\hline Room Temperature $\left({ }^{0} \mathrm{C}\right)$ & $36.3 \pm 0.31$ & $36.4 \pm 0.025$ & $36.2 \pm 0.025$ \\
\hline Testis temperature $\left({ }^{0} \mathrm{C}\right)$ & $26.0 \pm 0.0$ & $26.0 \pm 0.0$ & $26.0 \pm 0.0$ \\
\hline Stored milt temperature $\left({ }^{0} \mathrm{C}\right)$ & $26.3 \pm 0.0^{\mathrm{a}}$ & $7.42 \pm 1.76^{\mathrm{b}}$ & $1.3 \pm 0.18^{\mathrm{c}}$ \\
\hline Live weight $(\mathrm{kg})$ & $0.64 \pm 0.017^{\mathrm{a}}$ & $0.61 \pm 0.01^{\mathrm{b}}$ & $0.61 \pm 0.008^{\mathrm{b}}$ \\
\hline Standard body length $(\mathrm{cm})$ & $42.38 \pm 0.84$ & $42.57 \pm 0.43$ & $43.1 \pm 0.16$ \\
\hline Total body length $(\mathrm{cm})$ & $48.33 \pm 0.34^{\mathrm{b}}$ & $48.15 \pm 0.17^{b}$ & $50.18 \pm 0.24^{\mathrm{a}}$ \\
\hline Papilla length $(\mathrm{cm})$ & $1.79 \pm 0.066^{\mathrm{a}}$ & $1.5 \pm 0.08^{b}$ & $1.59 \pm 0.048^{b}$ \\
\hline Left fin length $(\mathrm{cm})$ & $12.5 \pm 0.58^{\mathrm{a}}$ & $8.5 \pm 1.3^{\mathrm{b}}$ & $13.25 \pm 0.95^{\mathrm{a}}$ \\
\hline Right fin length $(\mathrm{cm})$ & $11.0 \pm 0.0^{\mathrm{b}}$ & $13.25 \pm 0.96^{\mathrm{a}}$ & $11.75 \pm 0.5^{\mathrm{b}}$ \\
\hline Left testis length $(\mathrm{cm})$ & $4.69 \pm 0.047^{\mathrm{b}}$ & $5.32 \pm 0.34^{\mathrm{a}}$ & $5.5 \pm 0.08^{a}$ \\
\hline Right testis length $(\mathrm{cm})$ & $4.74 \pm 0.045^{\mathrm{c}}$ & $6.13 \pm 0.12^{\mathrm{a}}$ & $5.6 \pm 0.08^{b}$ \\
\hline
\end{tabular}

$a, b, c:$ Means with different letters on the same row are significantly different at $P<0.05 ; \pm S T D$ : Plus or minus standard deviation; T1: Bench temperature (control: without refrigeration); T2: Fridge temperature; T3: Freeze temperature.

The effect of different storage time interval on African catfish milt quality is shown in Table 2 . There were significant differences $(\mathrm{P}<0.05)$ in all the parameters monitored across the treatments except at 0 minute, where the alive sperm cells, dead sperm cells, active motile sperm cells and sluggish motile sperm cells values did not differ statistically $(\mathrm{P}>0.05)$. The milt volume mean value was highest $(0.61$ $\mathrm{ml})$ in $\mathrm{T}_{2}$ followed by $\mathrm{T}_{1}(0.5 \mathrm{ml})$ and $\mathrm{T}_{3}$ where $0.4 \mathrm{ml}$ was recorded. It was observed that milt $\mathrm{pH}$ mean values which ranged from 6.85 to 8.9 , were not persistently different $(\mathrm{P}>0.05)$ across the treatments in $\mathrm{T}_{2}$ and $\mathrm{T}_{3}$, but both values differed significantly $(\mathrm{P}<0.05)$ from that of $\mathrm{T} 3$. At 0 minute, the values of alive sperm cells, dead sperm cells, active motile sperm cells and sluggish motile sperm cells varied between 75 and 79\%, 21 and 25\%, 72 and 76\% as well as 24 and $28 \%$ in that order. Whereas, at 15 minutes, the values deteriorated to between 1.5 and $4 \%$ alive sperm cells, 96 and 98.5\% dead sperm cells, 7.25 and $17.5 \%$ active motile sperm cells and sluggish sperm cells varied from 82.5 to $92.8 \%$. At 30 minutes and beyond, absolutely $100 \%$ dead sperm cells were recorded except at 1 hour, where $0.25 \%$ of the Freeze milt $\left(\mathrm{T}_{3}\right)$ was alive and out of this value, only $24 \%$ was actively motile while $76 \%$ was sluggish. The sperm cells concentration value which varied from 5.62 $-6.54 \times 10^{9}$ across the treatments, was consistently superior in $T_{2}$ followed by $T_{1}$ and $T_{3}$ respectively.

Table2. Effect of different storage time interval on African catfish milt quality

\begin{tabular}{|c|c|c|c|c|c|c|c|c|c|c|c|c|c|c|c|c|c|c|}
\hline \multirow{3}{*}{$\begin{array}{c}\text { Para } \\
\text { mete } \\
\text { rs } \\
\end{array}$} & \multicolumn{18}{|c|}{ Treatments $( \pm$ STD $)$} \\
\hline & \multicolumn{3}{|c|}{ O minute ${ }^{*}$} & \multicolumn{3}{|c|}{15 minutes * } & \multicolumn{3}{|c|}{30 minutes * } & \multicolumn{3}{|c|}{45 minutes ${ }^{\text {* }}$} & \multicolumn{3}{|c|}{1 hour* } & \multicolumn{3}{|c|}{ 1:15 hour* } \\
\hline & $\mathbf{T}_{1}$ & $\mathbf{T}_{2}$ & $\mathbf{T}_{3}$ & $\mathbf{T}_{1}$ & $\mathbf{T}_{2}$ & $\mathbf{T}_{3}$ & $\mathbf{T}_{1}$ & $\mathbf{T}_{2}$ & $\mathbf{T}_{\mathbf{3}}$ & $\mathbf{T}_{1}$ & $\mathbf{T}_{2}$ & $\mathbf{T}_{\mathbf{3}}$ & $\mathbf{T}_{1}$ & $\mathbf{T}_{2}$ & $\mathbf{T}_{3}$ & $\mathbf{T}_{1}$ & $\mathbf{T}_{2}$ & $\mathbf{T}_{3}$ \\
\hline$\Phi \mathrm{MV}$ & $0.5 \pm$ & 0.61 & $0.4 \pm$ & $0.5 \pm$ & 0.61 & $0.4 \pm$ & $0.5 \pm$ & 0.61 & $0.4 \pm$ & $0.5 \pm$ & 0.61 & $0.4 \pm$ & $0.5 \pm$ & 0.61 & $0.4 \pm$ & $0.5 \pm$ & 0.61 & $0.4 \pm$ \\
\hline$(\mathrm{ml})$ & $0^{\mathrm{b}}$ & $\begin{array}{c} \pm \\
0.0^{\mathrm{a}}\end{array}$ & $0.0^{c}$ & $0.0^{\mathrm{b}}$ & $\begin{array}{c} \pm \\
0.0^{\mathrm{a}}\end{array}$ & $0.0^{\mathrm{c}}$ & $0.0^{\mathrm{b}}$ & $\begin{array}{c} \pm \\
0.0^{\mathrm{a}}\end{array}$ & $0.0^{c}$ & $0.0 \mathrm{~b}$ & $\begin{array}{r} \pm \\
0.0\end{array}$ & $0.0^{c}$ & $0.0^{\mathrm{b}}$ & $\begin{array}{c} \pm \\
0.0^{\mathrm{a}}\end{array}$ & $0.0^{c}$ & $0.0^{\mathrm{b}}$ & $\begin{array}{c} \pm \\
0.0^{\mathrm{a}}\end{array}$ & $0.0^{\mathrm{c}}$ \\
\hline Milt & $7.8 \pm$ & 6.95 & 6.95 & $7.90 \pm$ & 6.95 & 6.87 & $7.6 \pm$ & $7.0 \pm$ & 6.85 & $8.9 \pm$ & 6.92 & 6.85 & $3.8 \pm$ & $7.0 \pm$ & $6.85 \pm$ & $8.8 \pm$ & $7.0 \pm$ & 6.85 \\
\hline $\mathrm{pH}$ & $0.2^{\mathrm{a}}$ & $\begin{array}{c} \pm \\
0.1^{\mathrm{b}}\end{array}$ & $\begin{array}{c} \pm \\
0.06 \\
\mathrm{~b}\end{array}$ & $0.11^{\mathrm{a}}$ & $\stackrel{ \pm}{ \pm} 0.1^{\mathrm{b}}$ & $\begin{array}{c} \pm \\
0.05 \\
\mathrm{~b}\end{array}$ & $\begin{array}{c}0.46 \\
\mathrm{a}\end{array}$ & $0.2^{\mathrm{b}}$ & $\begin{array}{c} \pm \\
0.1^{\mathrm{b}}\end{array}$ & $0.0 \mathrm{a}$ & $\begin{array}{c} \pm \\
0.0^{\mathrm{b}}\end{array}$ & $\begin{array}{c} \pm \\
0.1^{\mathrm{b}}\end{array}$ & $0.0^{\mathrm{a}}$ & $0.2^{\mathrm{b}}$ & $0.1^{\mathrm{b}}$ & $0.0^{\mathrm{a}}$ & $0.2^{\mathrm{b}}$ & $\begin{array}{c} \pm \\
0.1^{\mathrm{b}}\end{array}$ \\
\hline$\overline{A S C}$ & $79 \pm$ & $5 \pm$ & $78 \pm$ & $4.00 \pm$ & 1.50 & $1.5 \pm$ & $0.0 \pm$ & $0.0 \pm$ & $0.0 \pm$ & $0.0 \pm$ & $0.0=$ & $0.0 \pm$ & $0.0 \pm$ & $0.0 \pm$ & $0.25 \pm$ & $0.0 \pm$ & $0.0 \pm$ & 0.0 \\
\hline$(\%)$ & 1.2 & 1.3 & 2.7 & $1.15^{\mathrm{a}}$ & $\begin{array}{c} \pm \\
0.58 \\
\mathrm{~b}\end{array}$ & $\begin{array}{c}0.57 \\
\mathrm{~b}\end{array}$ & 0.0 & 0.0 & 0.0 & 0.0 & 0.0 & 0.0 & 0.0 & 0.0 & 0.5 & 0.0 & 0.0 & 0.0 \\
\hline DSC & $21 \pm$ & $25 \pm$ & $22 \pm$ & $96 \pm$ & 98.5 & 98.5 & 100 & 100 & 100 & 100 & 100 & 100 & 100 & 100 & 99.75 & 100 & 100 & 100 \\
\hline$(\%)$ & 1.1 & 1.2 & 2.7 & $1.2^{\mathrm{b}}$ & $\begin{array}{c} \pm \\
0.57\end{array}$ & $\begin{array}{c} \pm \\
0.58\end{array}$ & $\begin{array}{c} \pm \\
0.0\end{array}$ & $\begin{array}{c} \pm \\
0.0\end{array}$ & $\begin{array}{c} \pm \\
0.0\end{array}$ & $\begin{array}{c} \pm \\
0.0\end{array}$ & $\begin{array}{c} \pm \\
0.0\end{array}$ & $\begin{array}{c} \pm \\
0.0\end{array}$ & $\begin{array}{c} \pm \\
0.0\end{array}$ & $\begin{array}{c} \pm \\
0.0\end{array}$ & $\begin{array}{c} \pm \\
0.5\end{array}$ & $\begin{array}{c} \pm \\
0.0\end{array}$ & $\begin{array}{c} \pm \\
0.0\end{array}$ & $\begin{array}{c} \pm \\
0.0\end{array}$ \\
\hline
\end{tabular}




\begin{tabular}{|c|c|c|c|c|c|c|c|c|c|c|c|c|c|c|c|c|c|c|}
\hline & & & & & $\mathrm{a}$ & $\bar{a}$ & & & & & & & & & & & & \\
\hline AMS & $72 \pm$ & $76 \pm$ & $75 \pm$ & $7.25 \pm$ & $9.0 \pm$ & 17.5 & $0.0 \pm$ & $0.0 \pm$ & $0.0 \pm$ & $0.0 \pm$ & $0.0 \pm$ & $0.0 \pm$ & $0.0 \pm$ & $0.0 \pm$ & $23.8 \pm$ & $0.0 \pm$ & $0.0 \pm$ & $0.0 \pm$ \\
\hline $\begin{array}{c}\mathrm{C} \\
(\%)\end{array}$ & 4.8 & 13.4 & 15.0 & 6.39 & 7.11 & $\begin{array}{c} \pm \\
9.6\end{array}$ & 0.0 & 0.0 & 0.0 & 0.0 & 0.0 & 0.0 & 0.0 & 0.0 & 7.5 & 0.0 & 0.0 & 0.0 \\
\hline SMS & $28 \pm$ & $24 \pm$ & $25 \pm$ & $92.8 \pm$ & 91.0 & 82.5 & $0.0 \pm$ & $0.0 \pm$ & $0.0 \pm$ & $0.0 \pm$ & $0.0 \pm$ & $0.0 \pm$ & $0.0 \pm$ & $0.0 \pm$ & $76.2 \pm$ & $0.0 \pm$ & $0.0 \pm$ & $0.0 \pm$ \\
\hline $\begin{array}{c}\mathrm{C} \\
(\%)\end{array}$ & 4.8 & 13.4 & 15.0 & 6.39 & $\begin{array}{c} \pm \\
7.12\end{array}$ & $\begin{array}{c} \pm \\
9.6\end{array}$ & 0.0 & 0.0 & 0.0 & 0.0 & 0.0 & 0.0 & 0.0 & 0.0 & 42.5 & 0.0 & 0.0 & 0.0 \\
\hline${ }^{\phi} \mathrm{SCC}$ & 566 & 654 & 562 & $566 \pm$ & 654 & 562 & 566 & 654 & 562 & 566 & 654 & 562 & 566 & 654 & $562 \pm$ & 566 & 654 & 562 \\
\hline$\left(\mathrm{x} 10^{9}\right.$ & \pm & \pm & \pm & $4.6^{\mathrm{b}}$ & \pm & \pm & \pm & \pm & \pm & \pm & \pm & \pm & \pm & \pm & $27.9^{c}$ & \pm & \pm & \pm \\
\hline ) & $4.6^{b}$ & $6.0^{\mathrm{a}}$ & $\begin{array}{c}27.9 \\
\mathrm{c}\end{array}$ & & $6.0^{\mathrm{a}}$ & $\begin{array}{c}27.9 \\
\mathrm{c}\end{array}$ & $4.6^{\mathrm{b}}$ & $6.0^{\mathrm{a}}$ & $\begin{array}{c}27.9 \\
\mathrm{c}\end{array}$ & $4.6^{\mathrm{b}}$ & $6.0^{\mathrm{a}}$ & $\begin{array}{c}27.9 \\
\mathrm{c}\end{array}$ & $4.6^{\mathrm{b}}$ & $6.0^{\mathrm{a}}$ & & $4.6^{\mathrm{b}}$ & $6.0^{\mathrm{a}}$ & $\begin{array}{c}27.9 \\
\mathrm{c}\end{array}$ \\
\hline
\end{tabular}

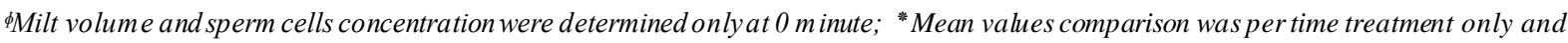
not across treatments; $a, b, c$ : Means with different letters on the same row at the same time per treatment are significantly different at $P<0.05$; $\pm S T D$ : Plus or minus Standard deviation; $T_{1}\left(26.3^{\circ} \mathrm{C}\right)$ : Bench temperature (control: without refrigeration); $T_{2}\left(7.42^{\circ} C\right):$ Fridge temperature; $T_{3}\left(1.3^{\circ} \mathrm{C}\right)$ : Freeze temperature; MV: Milt volume; ASC: Alive sperm cells; DSC: Dead sperm cells; AMSC: Active motile sperm cells; SMSC: Sluggish motile sperm cells; SCC: Sperm cells concentration.

\section{DISCUSSION}

The results indicated that the milt storage temperatures varied considerably and the values were within 1 to $7^{\circ} \mathrm{C}$ described as preservation and storage temperature [25]. It was shown that the body linear parameters were similar to those reported in African mudfish caught in a dam [26]. However, the live weight value was lower than $0.79-1.0 \mathrm{~kg}$ reported [27] in captive African mudfish at 8 months old yet, the standard body and total body length values were similar. This observation probably showed that at maturity, the body linear values may not increase irrespective of the final body weight attained, suggesting that the experimental fish were perhaps sexually matured. The high sperm cells concentration recorded in this study, compared favourably well with $5.16 \times 10^{8}$ reported in C. gariepinus [28] thus further strengthen the assertion that the experimental fish were perhaps sexually matured.

It was observed that at 0 minute, the milt quality evaluation was best and at 1 hour however, some alive and motile sperm cells were observed but the motility level was so low that it may probably have little or no fertilizing ability if used in spawning according to several reports [18, 19, and 29]. This possibly suggested that refrigeration storage of milt without cryopreservation materials may not be suitable in artificial insemination in captive catfish production. This observation apparently validated several reports, on the need for cryopreservation in artificial breeding operation in African catfish [14, 20, 28, and 30].

\section{CONCLUSiON}

The body linear measurements indicated that the experimental fish were sexually matured with very high sperm cells concentration, indicative of high potential fertilizing ability if used in spawning immediately or if properly preserved and stored. It was however revealed that Fridge and Freeze temperatures could not prevent the degenerative biochemical processes in catfish milt not extended with cryopreservation materials. This was what probably resulted in the poor milt quality recorded at 15 minutes of storage and the deteriorated motility observed after 15 minutes of storage even with refrigeration. As a result, Fridge and Freeze temperatures may not be feasible in preserving or storing unprocessed catfish milt.

\section{REFERENCES}

[1] Tengels G. G. A., systematic revision of the African species of the genus Clarias (Pisces: Clariidae). Annals Musee. Revue. African. Contributions, 247, 199 (1986). Available at http://dx.doi.org/ (last accessed 26 August, 2012).

[2] Sydenham D. H. J., New species of Clarias from West Africa. Rev. Zool. Afr., Vol. XCIV, Fasc., 31, 659677. (1980).

[3] William R., Fish and Fisheries of Northern Nigeria. Ministry of Agriculture, Northern Nigeria. Gaskiya Corporation, Zaria. Pp. 83 (1967).

[4] Hecht T., Oellermann L. and Verheust L., Perspectives and Clariid catfish culture in Africa. In: Legendre, M. \& Proteau, and J-P. (Eds.). The Biology and Culture of Catfishes. Aquatic Living Resources. 9, 197206 (1996). Paris, Hors Series. 
[5] De Graaf G. J., Galemoni F. and Banzoussi, B., The artificial reproduction and fingerling production of the African catfish Clarias gariepinus (Burchell 1822) in protected and unprotected ponds. Aquaculture Research. 26, 233-242 (1995).

[6] FAO. Handbook on the artificial reproduction and pond rearing of the African catfish Clarias gariepinus in sub-Saharan Africa. Food and Agricultural Organization, Fisheries Technical Rome, Paper 362 (1996).

[7] Idahor K. O., Yakubu A. Umar A. F. Yahaya F. and Musa. L. A., Morphometric traits, spermatozoa microscopy and stripped eggs fertilization with milt collected from live African Mudfish (Clarias gariepinus). Livestock Research for Rural Development. 26, (8) (2014). http://www.lrrd.org/lrrd26/8/ idah26150.htm.

[8] Amupitan P. S., Ilori O. I., Aladele S. E., Odofin W. T. and Omitogun, O. G., Scaling up the viability of croyo reserved giant catfish semen in liquid nitrogen for commercial application. Proceedings of the 34th Annual Conference of the Genetic Society of Nigeria. NIHORT, Ibadan. Pp. 335-343 (2010). ISSN 01899686.

[9] Riley K. L. P., Refrigerated storage and cryopreservation of sperm for the production of Red snapper and Snapper hybrids. Master's Thesis, Agriculture and Mechanical College, Louisiana University. USA (2002).

[10] Bruton M. N., Alternative life-history strategies of catfishes. In: Legendre, M. and J. P. Proteau (Eds.).The Biology and culture of Catfishes. Aquatic Living Resources. Paris, Hors Series. 9, 35-41 (1996).

[11] Legendre M., Seasonal changes in sexual maturity and fecundity, and HCG-induced breeding of the catfish Heterobranchus longifilis Val. (Clariidae) reared in Ebrien lagoon (Ivory Coast). Aquaculture. 55, 201-213 (1986).

[12] Hogendoorn H., Controlled propagation of the African catfish, Clarias lazera (C\&V). I. Reproductive biology and field experiments. Aquaculture. 17, 323-333 (1979).

[13] Idahor K. O. Microscopic observation of spermatozoa in milt collected with syringe without sacrificing the male African Catfish (Clarias anguillaris B. 1911). International Journal of Fisheries and Aquatic Studies. 2, 88-91 (2014). www.fisheriesjournal.com.

[14] Omitogun O. G., Oyeleye O. O., Betiku C. O. Ojiokpota C., Aladele S. E. and Sarumi M. B., Potentials of short-term cryopreserved sperm of the giant African catfish, Clarias gariepinus (Burchell, 1822) for aquaculture in Nigeria. Proc. 31st Ann. Conf. of Genetic Society of Nigeria, Moor Plantation, Ibadan. Pp. 141-146 (2006).

[15] Viveen W. J. A. R, Richter C. J. J, van Oordt, P. G. W. J, Jansen J. A. L. and Huisman, E. A., Practical Manual for the Culture of the African Catfish (C. gariepinus) 2500 EB, The Hague, The Netherland. Pp. 94 (1996).

[16] Tonguthai K, China S, Limsuwan C, Somsiri T, Chanratchakool P, Kanchana khan et al. Handbook of hybrid catfish: Husbandry and health. Aquatic Animal Health Research Institute, Department of Fisheries, Kasetsart University Campus, Jatujak, Bangkok 10900, Thailand. Pp. 37 (1993).

[17] Hogendoorn H., Controlled propagation of the African catfish, Clarias lazera (C\&V). III. Feeding and growth of fry, Aquaculture, 21, 233-241 (1980).

[18] Bobe J. and Labbe C., Egg and Sperm Quantity in Fish. General and Comparative Endocrinology. 165, 535-548 (2010).

[19] Suquet M., Dreanno C., Fauvel C., Cosson J. and Billard R., Cryopreservation of sperm in marine fish. Aquaculture Research, 31, 231-243 (2000).

[20] Urbanyi B., Horvath A., Varga Z. and Horvath L., Effect of extenders on sperm cryopreservation of African catfish, Clarias gariepinus (Burchell). Aquaculture Research. 30, 145-151 (1999).

[21] Egbunike G. N., A toast for spermatozoa: One half the story of mammalian life. An Inaugural Lecture Series, University of Ibadan, Ibadan Nigeria. Pp. 58 (1995).

[22] SIGMA, Cell counting and cell viability. Saint Louis, MO 63178. Pp. 1634 (1994). USA.

[23] Prathalingam N. S. Holt W. W., Revell S. G., Jones S. and Watson P. E., The precision and accuracy of six different methods to determine sperm concentration. J. Andrology. 27, 257-262 (2006). DOI: $10.2164 /$ jandrol.05112

[24] SAS, Statistical Analysis System, User's Guide. Statistical. Version 9.1 e4d. SAS. Inst. Inc. Cary. N.C. USA (2012).

[25] FAO, Preservation techniques: Fish utilization and trade. Fisheries and Aquaculture Department, Rome. Food and Agriculture Organization of the United Nations for a world without hunger. (2017). Available at http://www.fao.org/fishery/utilization_trade/en (last accessed 21 November 2017).

[26] Okunsebor S. A and Idahor K. O., Use of morphological and haematological indices of African Mudfish (Clarias gariepinus) to assess Doma Dam water quality. Proceedings of the 14th Annual Conference of Animal Science Association of Nigeria, LAUTECH, Ogbomoso. Pp. 559-561 (2009). 
[27] Idahor K. O., Anatomical study of testes position in African Mudfish (Clarias gariepinus): guide to milt harvesting without sacrificing the fish. Journal of Animal Production Advances. 3, 265-270 (2013). DOI:10.5455/japa.20130919074634.

[28] Ayoola S. O., Relationships of chemical composition, quantity of milt to fertility and hatchability of Clarias gariepinus (Burchell, 1822). African Journal of Food, Agriculture, Nutrition and Development. 9, 1031-1045 (2009).

[29] Bart A. N. and Dunham R. A. Effects of sperm concentration and egg number on fertilization efficiency with channel catfish (Ictalurus punctatus) eggs and blue catfish (I. furcatus) spermatozoa. Theriogenology. 45, 673-682 (1996).

[30] Muchlisin Z. A., Hashim R. and Chong, A. S. C. Preliminary study on the cryopreservation of tropical bagrid catfish (Mystus nemurus) spermatozoa; the effect of extender and cryoprotectant on the motility after short-term storage. Theriogenology. 62: 25-34 (2004).

Citation: K. O. Idahor, et al., " Effect of Storage Temperature on African Catfish (Clarias Gariepinus Burchell 1822) Milt Quality", International Journal of Innovative Studies in Aquatic Biology and Fisheries, vol. 4, no. 1, p. 7-12, 2018. http://dx.doi.org/10.20431/2454-7670.0401002

Copyright: (C) 2018 Authors. This is an open-access article distributed under the terms of the Creative Commons Attribution License, which permits unrestricted use, distribution, and reproduction in any medium, provided the original author and source are credited. 